Бібліографічний опис для цитування: Pasichna Yu. Agrarianism: a new concept of understanding the Ukrainian revolution of 1917-1921. Український селянин. 2021. Вип. 25. С. 79-86. doi: 10.31651/2413-8142-2021-25-Pasichna

\title{
AGRARIANISM: A NEW CONCEPT OF UNDERSTANDING THE UKRAINIAN REVOLUTION OF
} 1917-1921

The article defines the concepts of agrarian history of the period of the Ukrainian revolution of $1917-1921$. The essence of the definition "concept" is analysed and the peculiarities of its application to the agrarian history of the period of the Ukrainian revolution are outlined. The concept of agrarianism as one of the agrarian concepts of the period of the Ukrainian revolution of 1917 - 1921 is investigated.

Key words: peasantry, Ukrainian revolution, concept, agrarianism.

Problem statement. Socio-political, socioeconomic and socio-cultural changes that took place during the Ukrainian Revolution of 1917 - 1921 became catalysts for the emergence of many phenomena. A separate place belonged to the agricultural component. Strengthening the interaction of world and domestic history, the need to modernize and update categorical Soviet judgments, outdated terms, methods, concepts and the ability to form their own independent historiographical, theoretical, methodological and practical assessment of historical processes are important for modern Ukrainian history. In view of this, the topic we raised in the article is relevant.

Resaerch analysis. M. Hrushevsky [1], V. Vynnychenko [2], D. Doroshenko [3], and I. Mazepa [4] were at the origins of understanding the events of the Ukrainian revolution. V. Verstyuk $[5 ; 6], \mathrm{V}$. Soldatenko [7; 8], and J. Hrytsak [9] made a separate contribution to the study of the role and place of the agrarian component. At the same time, the achievements of modern historical science significantly expand the already established ideas about the Ukrainian revolution of $1917-1921$.

The purpose of the article is to analyse the concept of agrarianism of the period of the Ukrainian revolution as a component of agrarian history.

The statement of the basic material. The study of the events of the Ukrainian revolution of 1917 - 1921 is carried out by researchers using general historical and special historical methods of scientific research. During the period of Ukraine's independence, historians turned to the study and understanding of complex sociopolitical and socio-economic processes of the Ukrainian revolution, using civilizational, modernization, sociocultural and other approaches.

Conditionally in the historiography of the history of the Ukrainian revolution, the following periods can be distinguished: 1) the period of the revolution of 1917 - 1921; 2) 1922 - the end of the 1980s; 3) the modern period: the beginning of the 1990s - the twenty-first century. 1922 - late $1980 \mathrm{~s} ; 3)$ the modern period: the beginning of the 1990 s - the twenty-first century. At the same time, the historiographical material processed by us gives grounds to clarify and detail the above periodization. Thus, in the Soviet historiography, we distinguish the following subperiods: 1) 1920s - 1930s; 2) $1930 \mathrm{~s}$ - the end of the $1980 \mathrm{~s}$.

The formation of historical knowledge about the concept of the Ukrainian revolution of 1917 - 1921 coincides in time with the events of 1917 - 1921. However, in the works of scientists of that time the concept of the Ukrainian revolution was not comprehensively studied. Some aspects of it are covered in fragments. This is due to the direct participation of researchers in the events of that time. Publication of the legacy of M. Hrushevsky, V. Vynnychenko, P. Skoropadsky, D. Doroshenko, as well as historians of the Ukrainian diaspora - O. Subtelny, T. Hunchak, I. Nagaevsky today is the source basis for the formation of the full image of the concept of the Ukrainian revolution. Among the researchers of agrarian history of this period it is worth noting V. Kaczynski [10].

In the 1920's and 1930's, the Soviet concept of the Ukrainian Revolution was formed, which diligently eradicated the very term "Ukrainian Revolution". Among the researchers of agrarian history of these years we can name S. Dumbrovsky [11], J. Yakovlev [12], A. Shestakov [13] and others.

With the release of "History of the CPSU (b). Short Course" in 1938, the concept of the Ukrainian revolution was considered only in the context of the concept of the October Revolution. Later, the term "revolution in Ukraine" became widespread. The 1930s and 1940s became years of stagnation for agrarian history, and it was not until the late 1950s that M. Rubach's publications were published [14]. It is with the name of this researcher that N. Kovalyova connects the focus of Soviet historians on agrarian issues [15].

The turn of the 1980s and 1990s opened up opportunities for rethinking the historical events of 1917 - 1921. It was at the turn of the 1980s and 1990s 
that research by agrarian historians V. Shanin and V. Danilov was carried out.

As R. Pyrig [16] rightly points out, the renewal of the term "Ukrainian Revolution" in independent Ukraine, and hence the first steps towards the formation of a new understanding of the concept of the Ukrainian Revolution, took place in 1996 with the Institute of Ukrainian History publishing a two-volume "History of Ukraine: A New Vision" edited by V. Smoliy. In it, V. Verstyuk proposed a new vision of the concept of the Ukrainian revolution, drew attention to the chronological boundaries of the period, as well as to the interpretation of the conceptual apparatus. J. Hrytsak's "Essay on the History of Ukraine" also in 1996 became not only a new tool for interpreting the events of 1917 1921 , but also complemented the general picture of the concept of the Ukrainian revolution [16, 45].

V. Soldatenko wrote in this regard that "it would be wrongful to speak of the concept of the Ukrainian revolution as something integral, complete, unchangeable" $[7,6]$. Historian on the basis of a thorough analysis of historiography, $d$ study of patterns, study of facts and documents substantiated the "concept of the Ukrainian revolution". V. Soldatenko uses the term "concept" as a synonym for the term "theory" [7, $108]$.

G. Korolyov argued that "the history of the Ukrainian revolution of 1917 - 1921 has all the hallmarks of a scientific concept" [17]: "the leading idea - the revival and consolidation of the Ukrainian nation to create their own state; historical time - the days of 1917 - 1921; the leading driver of national and social progress - the Ukrainian ethnic group and its political elite; a system of argumentation based on a thorough historiographical heritage and a strong source base (archival, archeographic, memoir and other segments)" [18, 7].

In 2016, the "concept of the Ukrainian revolution" received official recognition at the state level. The President of Ukraine P. Poroshenko by Decree №17 / 2016 of January 22, 2016 declared 2017 the Year of the Ukrainian Revolution 1917 - 1921, honouring events and prominent participants was identified as "one of the priorities of public authorities for 2017 - 2021" [19].

O. Mykhailyuk [20], O. Zhytkov [21], D. Arkhireysky [22], S. Kornovenko [23-25], V. Melnychenko [26], O. Kostenko [27 - 28], V. Lozovy [29 - 30], V. Masnenko [31], V. Tverdovsky [32] and other authors develop the concept of the Ukrainian revolution in their research. At the same time, modern researchers often widely use the term "Ukrainian national liberation struggle" as a synonym for the term "Ukrainian revolution", thus confirming the nationaldemocratic nature of the Ukrainian revolution [33].

Recent Ukrainian historians show an increased interest in the events of agrarian history during the Ukrainian Revolution of 1917 - 1921. This is confirmed by a large number of monographs and dissertations devoted to the study of these events. In modern research, the agrarian history of the period of the Ukrainian revolution of 1917 - 1921 is considered in several areas: analysis of land and agrarian transformations through the prism of political processes [34]; analysis of the socio-economic security of the peasantry and its relationship with the socio-political activity of the peasantry [35-40]; study of the impact of agrarian changes on the dynamics of state development in general.

In-depth study and rethinking of the events of the Ukrainian Revolution of 1917 - 1921, the formation of the concept of the Ukrainian Revolution and the possibility of developing new conceptual approaches to understanding the Ukrainian Revolution in general and the agrarian history of the Ukrainian Revolution in particular, in our opinion, became possible through scientific schools. It is worth noting a few scientific centres, which today historical science owes to the completed concepts. Among them: Institute of History of Ukraine of the National Academy of Sciences of Ukraine, Research Institute of Peasantry (Cherkasy), Centre for the Study of the History of Podillya at Ivan Ogienko National University of Kamyanets-Podilsky, Faculty of History of Oles Honchar Dnipropetrovsk National University, Research Laboratory on the History of Southern Ukraine at Zaporizhzhia National University, etc.

Some aspects of the concept of the Ukrainian revolution, agrarian history of the period of the Ukrainian revolution were reflected at the meetings of the All-Ukrainian symposia on agrarian history (Cherkasy), International scientific conferences "Revolutionary Upheavals of the Early Twentieth Century in Europe: Geopolitical, Sociocultural and Anthropological Dimensions" (Cherkasy), in the issues of collections of scientific works "Ukrainian Peasant" [41] and "Bulletin of Cherkasy University. Series "Historical Sciences" [42], in the collections "Scientific Works of the Historical Faculty of Zaporizhzhia State University" [43] and materials of scientific readings dedicated to the memory of D. P. Poida "Issues of Agrarian History of Ukraine and Russia" [44], etc.

A separate group of modern research consists of works that reflect the author's concepts or research within the existing concepts of agrarian history of the Ukrainian revolution. Among them we can single out the concept of the peasant revolution of 1902 - 1922, the author of which is V. Danilov [45]. Followers of the concept of the peasant revolution of 1902-1922 V. Danilov, among modern researchers, can be distinguished A. Kovalyova [15, 46-47], V. Glibishchuk [48] and others. S. Kornovenko, studying the socio-economic and socio-political transformations of the period of the Ukrainian Revolution of 1917 1921, offers an author's understanding of the concept of V. Danilov. The lower chronological boundary of the peasant revolution of V. Danilov S. Kornovenko proposes to date 1932. 1922, according to the author, can be considered the end of one and the beginning of the next stage, and considers the peasant as an active subject of agrarian history, the peasant-ideoman [4952]. N. Kovalyova, within the concept of V. Danilov, proposes the concept of "agrarian revolution in Ukraine in 1902 - 1922". The term "agrarian revolution" is used by the author in the study of economic relations between the peasantry, landlords and government.

Thus, historical knowledge about the period of the Ukrainian revolution of 1917 - 1921 in independent Ukraine not only allowed to complete the formation 
of a holistic concept of Ukrainian revolution, but also gave impetus to the formation of new ones. In this regard, J. Kalakura rightly remarks, noting that there is an increased interest in "... conceptualization or categorization of both natural and human sciences, including history" [15]. J. Kalakura explains this by globalization and the desire to preserve "... their distinctiveness, belonging to a certain identity..." [53].

If the author of the concept of the Ukrainian revolution cannot be identified, we can only talk about a long period of formation of this concept and the struggle of Ukrainian historians for its right to exist, the distinguishing feature of modern historical science is that researchers form authorial concepts, including agricultural history. methodological support of the concept as a tool of historical research.

In general, most encyclopaedic dictionaries [54 57] define the essence of the concept "concept" as "a system of views, concepts about certain phenomena or processes, the way they are understood, interpreted; the main idea of any theory, the main idea; the idea or plan of a new, original understanding; constructive principle of artistic, technical and other activities" [58]. This view is shared by historians who turn to the study of this term. For example, J. Kalakura notes that "a concept is a system of views or initial theoretical positions as a basis for research; the main idea or key idea of the study; system of evidence" $[53,13]$.

The application of the definition of "concept" to reveal the historical processes of the Ukrainian Revolution of 1917 - 1921 in general and the agrarian history of the Ukrainian Revolution in particular is effective, because it provides the formation of methodological apparatus, disclosure of the essence of concepts, application of general historical and special research methods. conceptual perspectives of further research.

According to the Encyclopaedia of Ukrainian History [58], the concept of "historical concept" is multifaceted, used to denote "a system of views on historical facts, a certain way of understanding, interpreting and generalizing historical phenomena and events, a system of evidence of certain historiographical positions, a set of historiographical facts, related to views on the historical processes of individual historians, scientific schools, areas, the main ideas that guide the author in the study of the historical process, etc" [59].

Thus, the concept of historical research should include research methodology, conceptual and categorical apparatus, analysis of source and documentary support of the research topic, theoretical understanding of the research topic, proof of sociopractical significance of the topic, disclosure of the topic for domestic and world history.

A new concept of agrarian history of the period of the Ukrainian revolution of $1917-1921$ is the concept of agrarianism of the period of the Ukrainian revolution of 1917 - 1921, proposed by S. Kornovenko. V. Telvak [60-61], V. Ilnytsky [62], V. Hlibishchuk [62], O. Kompaniets [63], and V. Lozovy [64] also joined its formation. The concept is based on understanding the essence of agrarianism as an Eastern European phenomenon, analysis of the views of G. Ruland,
A. Scheffle, J. Melin, who were the first to study agrarianism as an independent concept, determining the directions of movement of agrarianism to Central and South-Eastern Europe through Poland, Bulgaria, Romania, the Czech Republic and Slovakia.

Let us turn to the analysis of the proposed concept for the above analysed structural components.

First, the research methodology. The research methodology is based on such principles of historical knowledge as scientific, historicism, objectivity, systems analysis, etc., as well as on the application of general scientific, special-historical methods. The methodological basis of the concept is based on sociocultural and interdisciplinary approaches.

Secondly, the conceptual and categorical apparatus. S. Kornovenko analysed the essence of the concept of "agrarianism" in domestic and foreign scientific space and proposed the author's understanding of the essence of the concept as a phenomenon of the Ukrainian revolution: "the system of ideas about peasants, the peasants about themselves, about the peasantry as an active subject of history, capable of independent statebuilding; component of domestic economic policy aimed at solving the agrarian/peasant issue; as the peasants 'self-awareness of themselves, as the peasant's political culture and political consciousness, as the realization in practice of the peasants' hopes and ideas about their just future; component of socio- and partypolitical thought" [65].

Third, source-documentation provision. The studied concept is based on an array of sources that reveal the features of the relationship between the peasantry and the government, the solution of the agrarian issue, etc. and which are stored in the central and regional funds of Ukraine. Historiographical support is based on the analysis of foreign discourse in the study of agrarianism as a phenomenon of the Ukrainian revolution of 1917 - 1921. From the world community, the following scientists have been identified as representatives of the topic of agrarianism: J. Elland, Z. Hemmerling, R. Golets, A. Lech, B. Stochevskaya, A. Toshkov, M. Tomek, B. Trencheni, H. Schultz, A. Haare, J. Ryhlik, J. Garna, M. Novak, M. Brunklik, V. Havlik, V. Medzhetsky, W. Mueller, E. Cuba, I. Suaa, T. Lorenz and others [62].

Fourth, the theoretical understanding of the research topic. Compliance with this structural component of the concept is ensured by analysing different versions of agrarianism in Central and North-Eastern Europe and Ukraine, comparing the socio-political activity of the peasantry, studying the features of peasant legal consciousness, mentality and more. S. Kornovenko offers an author's explanation of the emergence of agrarianism as a Ukrainian phenomenon: "1) the semantic conflict between industrial and agricultural civilizations; 2) the agrarian type of Ukrainian society, respectively the agrarian nature of the Ukrainian nation, the development of the political culture of the actual agrarian nations; 3 ) the emergence of a new type of peasant, which in scientific and historical discourse is understood as a peasant-ideoman; such key ideologues of agrarianism as the peasant-centric phenomenon of the Ukrainian revolution of 1917 - 1921 are singled out: 1) uniqueness and indisputable value for mankind 
of the spiritual, moral, cultural and social properties inherent in the peasantry and its work; 2) recognition of the peasantry as a stratum capable of playing an independent role in political life; 3) not a capitalist, but a "separate" peasant way of society development, preservation of private property - small peasant property as its optimal regional variant and the basis of social progress, as well as the idea of a peasant cooperative state; 4) the predominance of agriculture and rural life over industry and the city, as well as the peasantry over other social groups; 5) the peasantry - the agricultural strata - concentrates the basic positive values and qualities of society, is the foundation of state stability and the bearer of national identity, and the above virtues should determine its political power".

Fifth, socio-practical significance for national and world history. The concept of agrarianism during the Ukrainian Revolution of 1917 - 1921 allows not only to rethink the Ukrainian Revolution as a historical phenomenon, but also to prove its peasant character and show that agrarianist practices of solving the agrarian issue are a component of both world and Ukrainian history.

In our opinion, the concept of agrarianism as a phenomenon of the Ukrainian revolution is not only an opportunity to rethink and study the agrarian issue to prevent similar issues in modern space, but also an opportunity to enter the world as a self-sufficient historical concept that does not require proof, because, citing a significant number of works on the concept of the Ukrainian revolution of 1917 - 1921, the world community does not have a permanent tradition of its recognition and constantly to question it [17].

The conclusions. The issues of agrarian transformation, as a hundred years ago, are an important aspect of state development. The historical concept is the basis of scientific historical research. Its successful application allows to comprehensively analyse the research problem, to investigate the conceptual apparatus, to outline a set of methodological approaches, a system of research methods, to assess the current state of the research topic, to determine prospects for future research, to model individual processes of modern processes. The concept of agrarianism of the period of the Ukrainian revolution of $1917-1921$ is an opportunity to comprehend agrarian problems of the specified period from the standpoint of global trends in the development of historical science.

Acknowledgement. The author of the article are sincerely grateful to all members of the editorial board for the advice provided during doing the research and writing the article.

Financing. The article contains the results of research conducted under a grant from the National Research Fund of Ukraine «Agrarianism: the Peasantcentric Phenomenon of the Ukrainian Revolution of 1917 - 1921» (registration number 2020.02/0120).

\section{Bibliography:}

1. Грушевський М. Хто такі українці і чого вони хочуть. Київ: Либідь, 1991. 240 с.

2. Виннниченко В. Відродження нації. Київ: Видавництво політичної літератури України. 1990.

3. Дорошенко Д. Історія України 1917 - 1923 рр. Ужгород, 1930. Т. II.

4. Мазепа I. Україна в огні й бурі революції 1917-1921. Дніпро : Січ, 2002336 с.

5. Верстюк В. Українська революція: історичне значення та уроки. Україна в революційних процесах перших десятиліть XX століття. Київ: Інститут політичних і етнонаціональних досліджень ім. І. Ф. Кураса НАНА України. 2007. С. $33-43$.

6. Верстюк В. Українська революція: метаморфози, предмет, інтерпретація. Росія: діалог історіографій: матеріали міжнародної наукової конференції. Київ ; Чернігів: Деснянська правда. 2007. С. 128 - 134.

7. Солдатенко В. Революційний чинник в українській історії. Київ: Просвіта.1997. 416 с.

8. Солдатенко В. Феномен Української революції. Российская история. 2009. №1. С. 4 - 20.

9. Грицак Я. Україна модерна. 1997 - 1998. №2 - 3. Львів, 199.

10. Качинський В. Социализация сельського хозяйства на Украине. К. : Борьба, 1919. 30 с.

11. Думбровський С. Крестьянство в 1917 г. М. ; Ленинград : Госиздат, 1927. 148 с.

12. 1917 год в деревне / ред. Я Яковлева. М. ; Ленинград: 1929.360 с.

13. Шестков А. Очерки по сельському хозяйству и крестьянскому движению в годы войны и перед Октябрем 1917 г. Ленинград : Прибой. 1927. 191 с.

14. Рубач М. Очерки по истории революционного преобразования аграрных отношений на Украине в период проведения Октябрськой революции. К. Из-во АН УССР. 1957. 457 с.

15. Ковальова Н. Селяни, поміщики і держава: конфлікти інтересів. «Аграрна революція» в Україні $1902-1922$ рр. Дніпрпетровськ : Ліра, 2016.368 с.

16. Пиріг Р. Українська революція 1917-1921 років: сучасний історіографічний образ та дослідницький потенціал (стенограма наукової доповіді на засіданні Президії НАН України 22 листопада 2017 р.). Вісник Національної академї̈ наук України. 2018. № 1. С. 45-54.

17. Корольов Г. Концепція Української революції 1917-1921 років у текстах польських істориків: ставлення, традиція та історіографічний канон The Vision of the Ukrainian Revolution (1917-1921) in Researches of Polish Historians: Position, Tradition and Historiographical Canon. Проблеми вивчення історії Української револючї 1917 - 1921 рр.2017. Вип. 12. С. 43 - 60.

18. Нариси історії Української революції 1917-1921 років. / ред. В. Ф. Верстюк, Київ, 2011, Кн. 1. 390 с.

19. Указ Президента України №17/2016. URL: https://www.president.gov.ua/documents/172016-19736

20. Михайлюк О. Концепція «Української революції»: pro et contra. Гуманітарний журнал. 2009. № 3 - 4. С. 3 - 19.

21. Житков О. Селянознавчі дослідження в контексті формування концепції Української революції 1917 - 1921 рр. Наукові записки. Серія Історичні науки. 2013. Вип. 18. С. 146 - 153.

22. Архірейський Д. «Українська революція» (1917-1921 рр.): до проблеми логічного змісту терміну. Проблеми політичної історії Украӥни. 2019. Вип. 14. С. 155 - 167.

23. Kornovenko S. The Ukrainian revolution of 1917 - 1921: the peasant factor // Peasant Revolutionism during the Ukrainian Revolution of 1917-1921: Construction of the Peasant Republic. Banská Bystrica 2019. C. 8 - 21.

24. Корновенко С. Селянська революція 1917-1921 рр.: ліквідація поміщицького землеволодіння в Україні. Український селянин. 2015. Вип. 15. С. 55-61. 
25. Корновенко С. Суб’єктний складник аграрного питання як одна з передумов Української революції 1917-1921 рр. Украӥнський історичний журнал. 2017. № 4. С. 83-95.

26. Мельниченко В. Черкащина в добу Української революції 1917 - 1921 рр. Черкаси : Вертикаль, 2016.200 с.

27. Костенко О., Виноградов А. Українська революція: концепція, хронологія, періодизація. Українська національна революція 1917-1921 років крізь призму сучасності (до 100-річчя подіі). Полтава, 2017. С. 76-83.

28. Костенко О. Селяни в умовах Української революції 1917-1921 років. Сіверичина в історії України. 2017. Вип. 10. C. $356-359$.

29. Лозовий В. Українська революція та українська ментальність (1917-1921рр.). Краєзнавство. 2002.1 . С. 53-59.

30. Лозовий В. Селянська правосвідомість у добу Української революції (1917-1921 рр.). Український історичний журнал. 2005. № 6. С. 88-94.

31. Масненко В. Як українські селяни стали воїнами (до соціокультурних і мілітарних аспектів революції 1917-1921 рр.). Украӥнський селянин, 2018. Вип. 19. С. 49-59.

32. Твердовський А. Типологія державних утворень на українських землях періоду української національної революції 1917 - 1921 рр. Ч. 1. Наукові праці історичного факультету Запорізького національного університету. 2018. Вип. 50. С. $37-$ 55 .

33. Українська революція 1917-1921 рр.: передумови, процеси, наслідки, уроки. Межибіж: 2017.370 с.

34. Терлюк I. Аграрне питання як фактор правової політики українських державних формацій (1917 - 1921 рр.): започаткування національного земельного законодавства. URL: http:/science.lpnu.ua/sites/default/files/journal-paper/2017/ aug/5769/vnulpurn201685069.pdf

35. Мотенко Я. «Куркульство» як активний учасник селянського руху в Харківській губернії (1917 - 1921 pp.). URL: http://repository.kpi.kharkov.ua/handle/KhPI-Press/22669

36. Михайлюк О. Щодо «політичної програми» селянства України в період революції та громадянської війни. Украйнський селянин. 2003. Вип. 7. С. $102-106$.

37. Лозовий В. До питання про ідеологію українського селянства в добу революції (1917 - 1921 рр. Формування та діяльність українських національних урядів періоду Української революції 1917 - 1921 рр. : матеріали Bсеукраїнської наукової конферениї. Кам'янеиь-Подільський. 2008. С. $104-114$.

38. Куташев I. Масові селянські організації України в боротьбі за землю і волю (березень 1917 - квітень 1918 р.). Вісник Академї̈ праці і соичіальних відносин Федерації профспілок Украӥни. 2002. №3. С. 131 - 137.

39. Рябов О. Селянський повстанський рух у період Української революції 1917 - 1921 рр. (національно-державницькі чинники). Науковий вісник публічного та приватного права. 2018. Вип. 4. Т. 1. С. 21 - 25.

40. Нестеров О. Селянський повстанський рух на правобережній Україні (1919 р.): Дис... канд. іст. наук: 07.00.01/ Київський національний ун-т ім. Тараса Шевченка. Київ, 2001. 188 с.

41. URL: http://ukr-selianyn-ejournal.cdu.edu.ua/index

42. URL: http://history-ejournal.cdu.edu.ua/index

43. URL: http://old.istznu.org/page/369.ukr.html

44. Ковальова Н. Роль селянських з'їздів у формуванні програми дій українського селянства у 1917 р. Питання аграрної історї̈ України та Росї: матеріали п’ятих наукових читань, присвячених пам'яті професора Д. П. Пойди. 2004. С. 102-108.

45. Данилов В. Крестьянская револющия в России, $1902-1922$ г2. : из материалов конференции «Крестьяне и власть». 1996. Москва-Тамбов.

46. Ковальова В. Селянська революція в Наддніпрянській Україні 1902-1922 рр.: основні підходи до визначення поняття. Украйнський селянин. 2018. Вип. 19. С. 40-44.

47. Ковальова Н. Проблема обгрунтування початку «аграрної (селянької) революції» 1902 р. Гуржіївські історичні читання. 2014/2015. Вип. 8/9. С. 53-55.

48. Глібіщук М. Нові підходи до вивчення Російської революції 1917 - 1922). Iсторична панорама. 2017. Вип. 25. С. $25-33$

49. Корновенко С. Селянська революція 1917-1921 рр.: ліквідація поміщицького землеволодіння в Україні. Український селянин. 2015. Вип. 15. С. 55-61.

50. Корновенко С. Селянська революція в Україні початку ХХ ст.: хронологія і внутрішня періодизація. Український селянин. 2017. Вип. 17. С. 48-56.

51. Корновенко С. Селянські республіки початку ХХ століття як вияв селянської революційності в Україні. Украӥнський селянин.2017. Вип. 18. С. 29-41.

52. Корновенко С., Герасименко О. Селянин-бунтар. Селянська революція в Україні 1902-1917 рр. - Черкаси : Чабаненко Ю. А., 2017. 204 c.

53. Калакура Я. Методологічні засади концептуалізації української історіографії. Symposium historiographicum Czercasiensium = Черкаський історіографічний симпозіум. 2017. Т. II. С. 9-21.

54. Філософський енциклопедичний словник / ред. В. І. Шинкарук. Київ: Абрис 2002. 743 с.

55. Новая философская энциклопедия: в 4 т. / ред. В. С. Степин. М.: Мысль, 2010. Т. 2. 634 с.

56. Економічна енциклопедія. URL: http://slovopedia.org.ua/38/53402/380929.html»>КОНЦЕПЦІЯ

57. Академічний тлумачний словний $(1970$ - 1980). URL: http://sum.in.ua/s/koncepcija

58. Енциклопедія Сучасної України: електронна версія / редкол.: І.М. Дзюба, А.І. Жуковський, М.Г. Железняк. Київ: Інститут енциклопедичних досліджень НАН України, 2006. URL: http://esu.com.ua/search articles.php?id=3256

59. Енциклопедія історії України: Т. 5: Кон - Кю / ред. В. А. Смолій. Київ: Наукова думка, 2008. 568 c. URL: http://www. history.org.ua/?termin=Kontseptsiya Istorichna

60. Корновенко С., Тельвак $\overline{\mathrm{B}}$. Аграризм як селяноцентричний феномен країн Центральної та Південно-Східної Європи другої половини XIX - першої третини XX ст.: витоки і сутність явища. Український селянин. 2020. Вип. 24. С. 10 - 16.

61. Тельвак В., Корновенко С. «У нас уся надія, вся сила тільки в селянському, мужицькому народі»: аграристський дискурс дореволюційної публіцистики М. Грушевського. Проблеми гуманітарних наук: збірник наукових праць Дрогобицького державного педагогічного університету імені Івана Франка. Серія Історія. 2021. 6/48. 180-198.

62. Ільницький В., Глібіщук М., Компанієць О. Аграризм як селяноцентричний феномен Української революції 19171921 років у фокусі зарубіжної історіографії. Проблеми гуманітарних наук: збірник наукових праць Дрогобицького державного педагогічного університету імені Івана Франка. Серія Історія. 2020. 5/47. 214-234.

63. Компанієць О. Аграризм як селяноцентричний феномен Української революції 1917 - 1921 років у контексті розвитку європейського та північноамериканського аграризму XIX - першої третини XX століття: огляд зарубіжних джерел. Український селянин. 2020. Вип. 24. С. $86-92$.

64. Лозовий В. Джерельно-документальне забезпечення дослідження проблеми аграризму періоду Української революції 1917 - 1921 рр. Український селянин. 2020. Вип. 24. С. $92-97$.

65. Корновенко С., Тельвак В. Аграризм як селяноцентричний феномен країн Центральної та Південно-Східної Європи другої половини XIX - першої третини XX ст.: витоки і сутність явища. Український селянин. 2020. Вип. 24. С. 10 - 16. 


\section{References:}

1. Hrushevskyi, M. (1991). Khto taki ukraintsi i choho vony khochut. [Who are the Ukrainians and what they want]. Kyiv: Lybid. [in Ukrainian].

2. Vynnnychenko, V. (1990).Vidrodzhennia natsii. [Revival of the nation]. Kyiv: Vydavnytstvo politychnoi literatury Ukrainy. [in Ukrainian].

3. Doroshenko, D. (1930). Istoriia Ukrainy 1917 - 1923. [History of Ukraine 1917 - 1923]. Uzhhorod, II. [in Ukrainian].

4. Mazepa, I. (2002). Ukraina $v$ ohni y buri revoliutsii 1917-1921. [Ukraine in the fire and storm of the revolution of 19171921]. Dnipro : Sich. [in Ukrainian].

5. Verstiuk, V. (2007). Ukrainska revoliutsiia: istorychne znachennia ta uroky. Ukraina v revoliutsiinykh protsesakh pershykh desiatylit KhKh stolittia. [Ukrainian revolution: historical significance and lessons. Ukraine in the revolutionary processes of the first decades of the twentieth century]. Kyiv: Instytut politychnykh i etnonatsionalnykh doslidzhen im. I. F. Kurasa NANA Ukrainy. [in Ukrainian].

6. Verstiuk, V. (2007). Ukrainska revoliutsiia: metamorfozy, predmet, interpretatsiia. Rosiia: dialoh istoriohrafii: materialy mizhnarodnoi naukovoi konferentsii. [Ukrainian revolution: metamorphoses, subject, interpretation. Russia: dialogue of historiographies: materials of the international scientific conference]. Kyiv ; Chernihiv: Desnianska pravda. [in Ukrainian].

7. Soldatenko, V. (1997). Revoliutsiinyi chynnyk v ukrainskii istorii. [Revolutionary factor in Ukrainian history]. Kyiv: Prosvita. [in Ukrainian].

8. Soldatenko, V. (2009). Fenomen Ukrainskoi revoliutsii. [The phenomenon of the Ukrainian revolution]. Rossyiskaia ystoryia. [Russian history], 1, 4-20. [in Ukrainian].

9. Hrytsak, Ya. (1997 - 1998). Ukraina moderna. [Modern Ukraine], 2 - 3. Lviv. [in Ukrainian].

10. Kachinskiy, V. (1919). Sotsializatsiya selskogo hozyaystva na Ukraine. [Socialization of agriculture in Ukraine]. Kiev : Borba. [in Russian]

11. Dumbrovskiy, S. (1927). Krestyanstvo v 1917. [The peasantry in 1917]. Mockva ; Leningrad : Gosizdat. [in Russian]

12. 1917 god v derevne. [1917 in the village]. (1929). (Ed.) Ya. Yakovleva. Mockva ; Leningrad. [in Russian]

13. Shestkov, A. (1927). Ocherki po selskomu hozyaystvu i krestyanskomu dvizheniyu v godyi voynyi i pered Oktyabrem 1917. [Essays on agriculture and the peasant movement during the war and before October 1917]. Leningrad : Priboy. [in Russian]

14. Rubach, M. (1957). Ocherki po istorii revolyutsionnogo preobrazovaniya agrarnyih otnosheniy na Ukraine $\mathrm{v}$ period provedeniya Oktyabrskoy revolyutsii. [Essays on the history of the revolutionary transformation of agrarian relations in Ukraine during the October Revolution.]. Kiev : Iz-vo AN USSR. [in Russian]

15. Kovalova, N. (2016). Seliany, pomishchyky i derzhava: konflikty interesiv. «Ahrarna revoliutsiia»v Ukraini 1902 - 1922 rr. [Peasants, landowners and the state: conflicts of interest. «Agrarian Revolution» in Ukraine 1902 - 1922]. Dnipropetrovsk : LIRA. [in Ukrainian].

16. Pyrih, R. (2018). Ukrainska revoliutsiia 1917-1921 rokiv: suchasnyi istoriohrafichnyi obraz ta doslidnytskyi potentsial (stenohrama naukovoi dopovidi na zasidanni Prezydii NAN Ukrainy 22 lystopada 2017). [Ukrainian revolution of 1917-1921: modern historiographical image and research potential (transcript of the scientific report at the meeting of the Presidium of the NAS of Ukraine on November 22, 2017)]. Visnyk Natsionalnoi akademii nauk Ukrainy. [Bulletin of the National Academy of Sciences of Ukraine], 1, 45-54. [in Ukrainian].

17. Korolov, H. (2017). Kontseptsiia Ukrainskoi revoliutsii 1917-1921 rokiv u tekstakh polskykh istorykiv: stavlennia, tradytsiia ta istoriohrafichnyi kanon The Vision of the Ukrainian Revolution (1917-1921) in Researches of Polish Historians: Position, Tradition and Historiographical Canon. [The concept of the Ukrainian Revolution of 1917-1921 in the texts of Polish historians: attitude, tradition and historiographical canon The Vision of the Ukrainian Revolution (1917-1921) in Researches of Polish Historians: Position, Tradition and Historiographical Canon]. Problemy vyvchennia istorii Ukrainskoi revoliutsii 1917 - 1921. [Problems of studying the history of the Ukrainian revolution of 1917 - 1921], 12, 43 - 60. [in Ukrainian].

18. Narysy istorii Ukrainskoi revoliutsii 1917-1921 [Essays on the history of the Ukrainian revolution of 1917-1921]. (2011). $(E d)$. V. Verstiuk, Kyiv, 1. [in Ukrainian].

19. Ukaz Prezydenta Ukrainy №17/2016 [Decree of the President of Ukraine №17 / 2016]. Retrieved from https://www. president.gov.ua/documents/172016-19736 [in Ukrainian].

20. Mykhailiuk, O. (2009). Kontseptsiia «Ukrainskoi revoliutsii»: pro et contra. [The concept of the "Ukrainian revolution": pro et contra]. Humanitarnyi zhurnal. [Humanities magazine], 3 - 4, 3 - 19. [in Ukrainian].

21. Zhytkov, O. (2013). Selianoznavchi doslidzhennia v konteksti formuvannia kontseptsii Ukrainskoi revoliutsii $1917-1921$. [Peasant research in the context of forming the concept of the Ukrainian revolution of 1917 - 1921]. Naukovi zapysky. Seriia Istorychni nauky. [Scientific notes. Historical Sciences Series], 18, 146 - 153. [in Ukrainian].

22. Arkhireiskyi, D. (2019). «Ukrainska revoliutsiia» (1917-1921 rr.): do problemy lohichnoho zmistu terminu. ["Ukrainian Revolution" (1917-1921): to the problem of the logical meaning of the term]. Problemy politychnoi istorii Ukrainy. [Problems of political history of Ukraine.], 14, 155 - 167. [in Ukrainian].

23. Kornovenko, S. (2019). The Ukrainian revolution of 1917 - 1921: the peasant factor // Peasant Revolutionism during the Ukrainian Revolution of 1917-1921: Construction of the Peasant Republic. Banská Bystrica 2019. C. 8 - 21. [in English].

24. Kornovenko, S. (2015). Selianska revoliutsiia 1917-1921: likvidatsiia pomishchytskoho zemlevolodinnia v Ukraini. [Peasant revolution of 1917-1921: liquidation of landlordism in Ukraine]. Ukrainskyi selianyn. [Ukrainian peasant], 15, 55-61. [in Ukrainian].

25. Kornovenko, S. (2017). Subiektnyi skladnyk ahrarnoho pytannia yak odna z peredumov Ukrainskoi revoliutsii 1917-1921. [Subjective component of the agrarian question as one of the preconditions of the Ukrainian revolution of 1917-1921]. Ukrainskyi istorychnyi zhurnal. [Ukrainian historical journal], 4, 83-95. [in Ukrainian].

26. Melnychenko, V. (2016). Cherkashchyna v dobu Ukrainskoi revoliutsii $1917-1921$. [Cherkasy region in the days of the Ukrainian revolution of 1917 - 1921]. Cherkasy : Vertykal. [in Ukrainian].

27. Kostenko, O. \& Vynohradov A. (2017). Ukrainska revoliutsiia: kontseptsiia, khronolohiia, periodyzatsiia. Ukrainska natsionalna revoliutsiia 1917-1921 rokiv kriz pryzmu suchasnosti (do 100-richchia podii). [Ukrainian revolution: concept, chronology, periodization. The Ukrainian national revolution of 1917-1921 through the prism of modernity (to the 100th anniversary of the event).] Poltava. [in Ukrainian]

28. Kostenko, O (2017). Seliany v umovakh Ukrainskoi revoliutsii 1917-1921 rokiv. [Peasants in the conditions of the Ukrainian revolution of 1917-1921]. Sivershchyna $v$ istorii Ukrainy. [Severshchyna in the history of Ukraine], 10, 356 - 359. [in Ukrainian].

29. Lozovyi, V. (2002). Ukrainska revoliutsiia ta ukrainska mentalnist (1917-1921). [Ukrainian revolution and Ukrainian mentality (1917-1921)]. Kraieznavstvo. [Local lore], 1, 53-59. [in Ukrainian]. 
30. Lozovyi, V. (2005). Selianska pravosvidomist u dobu Ukrainskoi revoliutsii (1917-1921). [Peasant legal consciousness in the days of the Ukrainian revolution (1917-1921)]. Ukrainskyi istorychnyi zhurnal. [Ukrainian Historical Journal], 6, 88-94. [in Ukrainian].

31. Masnenko, V. (2018). Yak ukrainski seliany staly voinamy (do sotsiokulturnykh i militarnykh aspektiv revoliutsii 19171921). [How Ukrainian peasants became soldiers (to the socio-cultural and military aspects of the revolution of 1917-1921)]. Ukrainskyi selianyn. [Ukrainian peasant], 19, 49-59. [in Ukrainian].

32. Tverdovskyi, A. (2018). Typolohiia derzhavnykh utvoren na ukrainskykh zemliakh periodu ukrainskoi natsionalnoi revoliutsii 1917 - 1921. Ch. 1. [Typology of state formations in the Ukrainian lands during the Ukrainian national revolution of 1917 - 1921. Part 1.]. Naukovi pratsi istorychnoho fakultetu Zaporizkoho natsionalnoho universytetu. [Scientific works of the historical faculty of Zaporozhye National University], 50, 37-55. [in Ukrainian].

33. Ukrainska revoliutsiia 1917-1921: peredumovy, protsesy, naslidky, uroky. [Ukrainian revolution of 1917-1921: preconditions, processes, consequences, lessons]. (2017). Mezhybizh. [in Ukrainian].

34. Terliuk, I. Ahrarne pytannia yak faktor pravovoi polityky ukrainskykh derzhavnykh formatsii (1917 - 1921 rr.): zapochatkuvannia natsionalnoho zemelnoho zakonodavstva. [The agrarian question as a factor of legal policy of Ukrainian state formations (1917 - 1921): the beginning of national land legislation]. Retrieved from http://science.lpnu.ua/sites/default/files/journalpaper/2017/aug/5769/vnulpurn201685069.pdf [in Ukrainian].

35. Motenko, Ya. «Kurkulstvo» yak aktyvnyi uchasnyk selianskoho rukhu v Kharkivskii hubernii (1917 - 1921). ["The kulak" as an active participant in the peasant movement in the Kharkiv province (1917 - 1921).]. Retrieved from http://repository.kpi.kharkov. ua/handle/KhPI-Press/22669 [in Ukrainian].

36. Mykhailiuk, O. (2003). Shchodo «politychnoi prohramy» selianstva Ukrainy v period revoliutsii ta hromadianskoi viiny. [On the "political program" of the peasantry of Ukraine during the revolution and civil war]. Ukrainskyi selianyn. [Ukrainian peasant], 7, 102 - 106. [in Ukrainian].

37. Lozovyi, V. (2008). Do pytannia pro ideolohiiu ukrainskoho selianstva v dobu revoliutsii (1917 - 1921). [On the question of the ideology of the Ukrainian peasantry in the days of the revolution $(1917-1921)$ ]. Formuvannia ta diialnist ukrainskykh natsionalnykh uriadiv periodu Ukrainskoi revoliutsii 1917 - 1921: materialy Vseukrainskoi naukovoi konferentsii. [Formation and activity of Ukrainian national governments during the Ukrainian revolution of 1917 - 1921: materials of the All-Ukrainian scientific conference]. Kamianets-Podilskyi. [in Ukrainian].

38. Kutashev, I. (2002). Masovi selianski orhanizatsii Ukrainy v borotbi za zemliu i voliu (berezen 1917 - kviten 1918). [Mass peasant organizations of Ukraine in the struggle for land and freedom (March 1917 - April 1918)]. Visnyk Akademii pratsi i sotsialnykh vidnosyn Federatsii profspilok Ukrainy. [Bulletin of the Academy of Labor and Social Relations of the Federation of Trade Unions of Ukraine], 3, 131 - 137. [in Ukrainian].

39. Riabov, O. (2018). Selianskyi povstanskyi rukh u period Ukrainskoi revoliutsii 1917 - 1921. (natsionalno-derzhavnytski chynnyky). [Peasant insurgent movement during the Ukrainian Revolution of 1917 - 1921 (national-state factors)]. Naukovyi visnyk publichnoho ta pryvatnoho prava. [Scientific Bulletin of Public and Private Law.], 4, 1, 21 - 25. [in Ukrainian].

40. Nesterov, O. (2001). Selianskyi povstanskyi rukh na pravoberezhnii Ukraini (1919) [Peasant insurgent movement on the right bank of Ukraine (1919)]. Doctor's thesis. Kyiv. [in Ukrainian].

41. Retrieved from http://ukr-selianyn-ejournal.cdu.edu.ua/index

42. Retrieved from http://history-ejournal.cdu.edu.ua/index

43. Retrieved from http://old.istznu.org/page/369.ukr.html

44. Kovalova, N. (2004). Rol selianskykh zizdiv u formuvanni prohramy dii ukrainskoho selianstva u 1917. [The role of peasant congresses in the formation of the program of actions of the Ukrainian peasantry in 1917.]. Pytannia ahrarnoi istorii Ukrainy ta Rosii: materialy piatykh naukovykh chytan, prysviachenykh pamiati profesora D. P. Poidy. [Questions of agrarian history of Ukraine and Russia: materials of the fifth scientific readings dedicated to the memory of Professor D. P Poida], 102-108. [in Ukrainian].

45. Danilov, V. (1996). Krestyanskaya revolyutsiya v Rossii, 1902-1922 gg. [Peasant revolution in Russia, 1902-1922]: iz materialov konferentsii «Krestyane i vlast». Moskva-Tambov. [in Russian]

46. Kovalova, V. (2018). Selianska revoliutsiia v Naddniprianskii Ukraini 1902-1922: osnovni pidkhody do vyznachennia poniattia. [The Peasant Revolution in Dnieper Ukraine 1902-1922: Basic Approaches to Defining the Concept]. Ukrainskyi selianyn. [Ukrainian peasant], 19, 40-44. [in Ukrainian].

47. Kovalova, N. (2014/2015). Problema obhruntuvannia pochatku «ahrarnoi (seliankoi) revoliutsii» 1902. [The problem of substantiating the beginning of the "agrarian (peasant) revolution" of 1902]. Hurzhiivski istorychni chytannia. [Gurzhiyev's historical readings], 8/9, 53-55. [in Ukrainian].

48. Hlibishchuk, M. (2017). Novi pidkhody do vyvchennia Rosiiskoi revoliutsii $1917-1922)$. [New approaches to the study of the Russian Revolution of 1917 - 1922)]. Istorychna panorama. [Historical panorama], 25, 25-33. [in Ukrainian].

49. Kornovenko, S. (2015). Selianska revoliutsiia 1917-1921 rr.: likvidatsiia pomishchytskoho zemlevolodinnia v Ukraini. [Peasant revolution of 1917-1921: liquidation of landlordism in Ukraine]. Ukrainskyi selianyn. [Ukrainian peasant], 15, 55-61. [in Ukrainian].

50. Kornovenko, S. (2017). Selianska revoliutsiia v Ukraini pochatku KhKh st.: khronolohiia i vnutrishnia periodyzatsiia. [Peasant revolution in Ukraine in the early twentieth century: chronology and internal periodization.]. Ukrainskyi selianyn. [Ukrainian peasant], 17, 48-56. [in Ukrainian].

51. Kornovenko, S. (2017). Selianski respubliky pochatku XX stolittia yak vyiav selianskoi revoliutsiinosti v Ukraini. [Peasant republics of the early twentieth century as a manifestation of peasant revolution in Ukraine]. Ukrainskyi selianyn, 18 , 25-36. [in Ukrainian]

52. Kornovenko, S. \& Herasymenko, O. (2017). Selianyn-buntar. Selianska revoliutsiia v Ukraini 1902 - 1917 rr. [Peasantrebel. Peasant Revolution in Ukraine 1902 - 1917]. Cherkasy: Chabanenko Yu.A. [in Ukrainian].

53. Kalakura, Ya. (2017). Methodological principles of conceptualization of Ukrainian historiography. [Metodolohichni zasady kontseptualizatsii ukrainskoi istoriohrafii]. Symposium historiographicum Czercasiensium = Cherkasy historiographic symposium. [Symposium historiographicum Czercasiensium = Cherkaskyi istoriohrafichnyi symposium], II, 9 - 21. [in Ukrainian].

54. Filosofskyi entsyklopedychnyi slovnyk [Philosophical encyclopedic dictionary]. (2002). (Ed). V. Shynkaruk. Kyiv: Abrys. [in Ukrainian].

55. Novaya filosofskaya entsiklopediya [New philosophical encyclopedia]. (2010). (Ed.) V. S. Stepin. Moskva: Myisl, 2. [in Russian]

56. Ekonomichna entsyklopediia. [Economic encyclopedia]. Retrieved from http://slovopedia.org.ua/38/53402/380929. html"> КОНЦЕПЦІЯ [in Ukrainian].

57. Akademichnyi tlumachnyi slovnyi (1970 - 1980). [Academic Interpretive Vocabulary (1970 - 1980)]. Retrieved from http:// sum.in.ua/s/koncepcija [in Ukrainian].

58. Entsyklopediia Suchasnoi Ukrainy: elektronna versiia [Encyclopedia of Modern Ukraine: electronic version]. (2006). (Ed). I. Dziuba. Kyiv: Instytut entsyklopedychnykh doslidzhen NAN Ukrainy. [in Ukrainian]. 
59. Entsyklopediia istorii Ukrainy. [Encyclopedia of the History of Ukraine]. (2008). (Ed). V. Smolii. Kyiv: Naukova dumka. Retrieved from http://www.history.org.ua/?termin=Kontseptsiya_Istorichna

60. Kornovenko, S. \& Telvak, V. (2020) Ahraryzm yak selianotsentrychnyi fenomen krain Tsentralnoi ta Pivdenno-Skhidnoi Yevropy druhoi polovyny KhIKh - pershoi tretyny KhKh st.: vytoky i sutnist yavyshcha. [Agrarianism as a peasant-centric phenomenon of the countries of Central and South-Eastern Europe of the second half of the XIX - first third of the XX century: origins and essence of the phenomenon]. Ukrainskyi selianyn. (Ukrainian peasant), 24, 10 - 16. [in Ukrainian].

61. Telvak, V., \& Kornovenko, S. (2021). «U nas usia nadiia, vsia syla tilky v selianskomu, muzhytskomu narodi»: ahrarystskyi dyskurs dorevoliutsiinoi publitsystyky M. Hrushevskoho. ["We have all the hope, all the strength only in the peasant, peasant people": the agrarian discourse of pre-revolutionary journalism M. Hrushevsky.]. Problemy humanitarnykh nauk: zbirnyk naukovykh prats Drohobytskoho derzhavnoho pedahohichnoho universytetu imeni Ivana Franka. Seriia Istoriia. [Problems of humanities: collection of scientific works of Drohobych Ivan Franko State Pedagogical University. History Series]. 6/48, 180-198. [in Ukrainian].

62. Ilnytskyi, V., \& Hlibishchuk, M., \& Kompaniiets, O. (2020). Ahraryzm yak selianotsentrychnyi fenomen Ukrainskoi revoliutsii 1917-1921 rokiv u fokusi zarubizhnoi istoriohrafii. [Agrarianism as a peasant-centric phenomenon of the Ukrainian revolution of 1917-1921 in the focus of foreign historiography]. Problemy humanitarnykh nauk: zbirnyk naukovykh prats Drohobytskoho derzhavnoho pedahohichnoho universytetu imeni Ivana Franka. Seriia Istoriia. [Problems of humanities: a collection of scientific works of Drohobych State Pedagogical University named after Ivan Franko. History Series], 5/47, 214-234. [in Ukrainian].

63. Kompaniiets, O. (2020) Ahraryzm yak selianotsentrychnyi fenomen Ukrainskoi revoliutsii 1917 - 1921 rokiv u konteksti rozvytku yevropeiskoho ta pivnichnoamerykanskoho ahraryzmu KhIKh - pershoi tretyny KhKh stolittia: ohliad zarubizhnykh dzherel. [Agrarianism as a peasant-centric phenomenon of the Ukrainian revolution of 1917 - 1921 in the context of the development of European and North American agrarianism of the XIX - first third of the XX century: a review of foreign sources.]. Ukrainskyi selianyn. (Ukrainian peasant), 24, 86 - 92. [in Ukrainian].

64. Lozovyi, V. (2020) Dzherelno-dokumentalne zabezpechennia doslidzhennia problemy ahraryzmu periodu Ukrainskoi revoliutsii 1917 - 1921. [Source and documentary support for the study of the problem of agrarianism during the Ukrainian Revolution of 1917 - 1921] Ukrainskyi selianyn. (Ukrainian peasant), 24, 92 - 97. [in Ukrainian].

65. Kornovenko, S. \& Telvak, V. (2020) Ahraryzm yak selianotsentrychnyi fenomen krain Tsentralnoi ta Pivdenno-Skhidnoi Yevropy druhoi polovyny $\mathrm{KhIKh}$ - pershoi tretyny $\mathrm{KhKh}$ st.: vytoky i sutnist yavyshcha. [Agrarianism as a peasant-centric phenomenon of the countries of Central and South-Eastern Europe of the second half of the XIX - first third of the XX century: origins and essence of the phenomenon]. Ukrainskyi selianyn. (Ukrainian peasant), 24, 10 - 16. [in Ukrainian].

Ю. Г. Пасічна

кандидат історичних наук, фахівець відділу аспірантури, Черкаський національний університет імені Богдана Хмельницького, м. Черкаси, Украӥна ORCID: https://orcid.org/0000-0002-7357-7623 e-mail: pasichna_yulia@ukr.net

Bibliographic Description of the Article: Pasichna, Yu. (2021). Agrarianism: a new concept of understanding the Ukrainian revolution of 1917-1921. Ukrainskyi Selianyn. [Ukrainian peasant], 25, 79-86. (In Ukrainan). doi: 10.31651/2413-8142-2021-25-Pasichna

\section{АГРАРИЗМ: НОВА КОНЦЕПЦІЯ РОЗУМІННЯ УКРАЇНСЬКОї РЕВОЛЮЦІї 1917 - 1921 РР.}

Проблема. Суспільно-політичні, сочіально-економічні та соиіокультурні зміни, щуо відбулися в період Украӥнської революції 1917 - 1921 рр. стали каталізаторами появи багатьох феноменів. Окреме місце належало аграрному складнику. Посилення взаємовпливів світової та вітчизняної історії, необхідність осучаснення й оновлення категоричних радянських суджень, застарілих термінів, методів, концепиій та можливість формувати власну незалежну історіографічну, теоретико-методологічну та практичну очінку історичних прочесів є важливими для сучасної історії України. Зважаючи на це, порушена нами у статті тема є актуальною.

Мета - проаналізувати кониепиію аграризму періоду Української революиії як компонент аграрної історії.

Основні результати дослідження. Дослідження подій Української револючії 1917 - 1921 рр. відбувається із застосуванням дослідниками загально-історичних та спечіальних історичних методів наукового пошуку. Умовно в історіографії історії Украӥнської револючії можна виокремити такі періоди: 1) період революції 1917 - 1921 рр.; 2) 1922 - кінець 1980-х рр.; 3) сучасний період: початок 1990-х - ХХІ ст. 1922 - кінець 1980-х рр.; 3) сучасний період: початок 1990-х - ХХІ ст. Новою концепиією аграрної історї̈ періоду Украӥнської революиії 1917 - 1921 рр. $є$ концеепиія аграризму періоду Української револючії 1917 - 1921 рр., запропонована С. Корновенком. Кониепиія грунтується на осмисленні сутності аграризму як східноєвропейського феномену, аналізу поглядів Г. Руланда, А. Шефле, Ж. Меліна, які першими звертаються до вивчення аграризму як самостійної конщепиії, визначенні напрямі руху аграризму до Центральної та Південно-Східної Європи через Польщу, Болгарію, Румунію, Чехію і Словаччину.

Висновки. Проблеми аграрних перетворень, як і сто років назад, є важливим аспектом розвитку держави. Історична концепиія є основою наукового історичного пошуку. Ї̈ вдале застосування дозволяє всебічно проаналізувати досліджувану проблему, дослідити поняттєвий апарат, окреслити комплекс методологічних підходів, систему методів наукового дослідження, оиінити сучасний стан досліджуваної теми, визначити перспективи майбутніх досліджень, змоделювати окремі процеси сучасних процесів. Концепџія аграризму періоду Украӥнської револючї 1917 - 1921 рр. - можливість осягнути аграрні проблеми зазначеного періоду з позиції загальносвітових тенденцій розвитку історичної науки.

Ключові слова: селянство, Украӥнська революиія, концепція, аграризм.

Received 10.12.2020

Accepted 15.04.2021 